\title{
Erratum to: Distribution and ecotoxicological significance of polycyclic aromatic hydrocarbons in sediments from Iko River estuary mangrove ecosystem
}

\author{
Joseph P. Essien • Samuel I. Eduok •
}

Abass Abiola Olajire

Published online: 26 February 2015

(C) Springer International Publishing Switzerland 2015

Erratum to: Environ Monit Assess (2011) 176:99-107 DOI 10.1007/s10661-010-1569-2

The correct name is Samuel I. Eduok and not Stephen I. Eduok. The appropriate name is now shown above.

The online version of the original article can be found at http://dx. doi.org/10.1007/s10661-010-1569-2.

J. P. Essien · S. I. Eduok

Department of Microbiology, University of Uyo,

Uyo, Nigeria

\section{A. A. Olajire $(\bowtie)$}

Industrial and Environmental Chemistry Unit,

Department of Pure and Applied Chemistry, Ladoke

Akintola University of Technology,

Ogbomoso, Nigeria

e-mail: olajireaa@yahoo.com 